\title{
Tackling Gender poverty relations within Households through micro-credit Programs in Uganda
}

\author{
John Busingye \\ Ibanda University
}

\begin{abstract}
The study mainly set out to investigate the factors that influence gender relations in Uganda. This paper contributes to the body of knowledge by determining the local gender context influencing gender poverty relations in the face of micro-credit programs and practices in Uganda. The study was grounded on the feminist conflict theory. Women accessing and utilizing microcredit programs from Savings and Credit Cooperative Organizations (SACCOs) in Mbarara (MM) and Bushenyi-Ishaka Municipalities (BIM) of South West Uganda provided the contextual setting of the study. Data was collected from a total of 198 respondents by use of interviews and focused group discussions. The study findings show that age, women's marital status, the level of formal education, number of children depending on women, assets for collateral and signature requirements were the main factors influencing gender poverty relations within households in Uganda. The study contends that poverty and gender relations influence access to microcredit programs. The study then recommends that SACCOS should formulate gender inclusive strategies like alternative means of collateral and introduce women friendly modes of access to microcredit services as a strategy for tackling poverty among women in Uganda. The government is also advised to sensitize the public about gender poverty relations, human rights and increasing household income using the available media.
\end{abstract}

Key words: Micro-credit programmes, gender relations and household income.

\section{CONCEPTUAL BACKGROUND}

Poverty and gender relations delimit the entrepreneurial spirit of households and restrains women from making everyday decisions. Helm, (2006) puts it that; over 3 billion people who are living on less than $\$ 2$ (UGX7,000) per day who and do not access basic microcredit programs are the target in poverty reduction interventions. The experience of Sayed, Majid,Naruliza (2014), also shows that microcredit programs targeting the poor without access to a formal banking, is a strategy of poverty reduction and empowerment. In this regard, microcredit programs are intended to enable the poor including women without collaterals undertake income-generating activities, improve their livelihoods and cope with uncertainties (World Bank, 2007).

Surprisingly, the gender dimension of poverty shows that women because they often lack access to economic resources like capital; opportunities like education and support services; and do not have access to land, the source of livelihood are the poorest of the poor. Nevertheless, women are physically engaged in income generating activities and support the livelihood in their households (Kariuki, 2013). Due to factors like breaking of families, wars, HIV-related morbidity and mortality poverty within households is also increasing; a trend called "feminisation of poverty" (Grabka 2013). Accordingly, microcredit programs targeting women is a strategy being advanced for poverty reduction and women's empowerment in developing countries (Ebimobowei, Sophia, \& Wisdom, 2012). Advocates of this strategy argue that poverty tackling microcredit programs strengthen women's bargaining position within the 
households and allow them to influence decision making within their patriarchal communities. Thus this study pursued to describe the factors influencing access to and utilization of microcredit among women as a strategy to tackle poverty, increase household income and gender relations.

\section{Contextualizing women's economic status and gender relations in Uganda}

Studies from Africa (Nwigwe, Omonona, \& Okoruwa (2012) suggest that the status of women in rural areas, grow most of the food crops and fetch water and fuel. Women also do much of the work on cash crops, some like piggery, poultry, knitting, and work on other people's crops to earn cash, and do non-agricultural work for cash as well as participate in community selfhelp activities. Despite all these economic activities, women are on average the poorest of the community in Africa and continue to be marginalized (Chant, 2006). Women in Uganda are no exception. These women perform most of the agricultural and household work as well as caring for other members of the society. In contrast, in urban areas, most women are largely engaged in petty enterprises within the informal sector, stereotyped by gender, with little capital investment and operate on low turnovers where prospects for growth and upward mobility are small. Such petty enterprises include street/roadside and market vending; projects of urban farming like gardening, piggery, poultry; knitting, small retail shops, mobile money kiosks, food vending, bars and restaurants.

Women poverty and gender relations in Uganda are associated with inadequate education, social prejudices and lack of legal rights (Agriculture Support Programme 2010). Culturally women are not expected to inherit property and carry out big investments. In the labour market, women are more vulnerable, since the cultural norms value men as breadwinners. These factors can handicap women in accessing and utilizing micro-credit programs obstructing them from investing in income generating ventures for economic and social benefits. Women's poor access to microcredit programs is also attributed to their lack of education, skills and training, as well as patriarchal traditions (Niehof \& Tilburg2010). On a related note, this situation can be seen as a manifestation of the gender division of labour (Cleaver, \& Hamada 2010). In this context, thus this study pursued to describe the factors influencing access to and utilization of micro-credit programmes among women as a strategy to tackle poverty, increase household income and gender relations.

\section{Problem statement}

The lax of access to micro-credit programmes are compounded by the recommended gender relations within societies that treat women as subordinates, making women more susceptible to poverty. Men in Uganda are not only the heads of households but also extend their tentacles to control resources in possession of their wives and female relatives. This is because gender relations in the household and the community favour men dominance over all family resources. Micro-credit programs are a means to reverse this situation by increasing household income. Well knowing that studies linking micro-credit programs and household incomes have been undertaken, such studies have concentrated on increasing household income with a few addressing the gender relations with in household settings. Hitherto, it is steadily noted that there are fundamental gender relations in the household that affect access to and utilization of micro-credit programs among women in Uganda.

\section{Theoretical perspective and literature review}

This study was grounded on the feminist conflict theory advanced by Blumberg $(1984,2005)$. Blumberg feminist conflict theory $(1984,2005)$ is the most applicable in classifying poverty, gender relations and the difficulty situation of women in the society. This theory hypothesizes that gender stratification is eventually driven by the degree to which, relative to men, women 
control the means of production and the allocation of productive surplus or surplus value. Consequently, it is the understanding that society is diverse, and gender stratification commands the base of power relations within the family, which is a reflection of culturally defined gender-ideologies and gender-segregated resources in the wider society. The observation of the theory is that stratification is focused by the way allocation of productive resources in society is undertaken for example, allocating land to men, and not women. Blumberg further contends that when women mobilize less economic power they are oppressed physically, politically and ideologically. Again, when women's economic power relative to men is growing, men are likely to perceive such changes as threats. Thus, men attempt to suppress, physically and politically, women's efforts to gain equal power. Chafetz (1990) supports Blumberg's contention and plugs out that successful mobilization of resources by women generates a sense of power that often threatens male spouses. The concern of the theory is that women are oppressed yet they are considered doing reproduction work which is less valuable with penny contribution to the economy. Feminists argue that women's work ought to be valued and given equal pay for equal work with men and this ensures increased household income, gender equality and improved gender relations in households. In addition, the theory presumes that gender inequalities will exist when men control disproportionate resources and, conversely, gender imbalances would decline as women gain household income and political ideologies. Blumberg (2005) further maintains that enhancing women's economic empowerment boosts gender equality, as women gain more power in the household and community. He further proclaims that women's economic empowerment results into increased incomes, self-confidence, and that woman and men tend to spend their income differently at micro and macro levels.

Based on the above theory, women in Uganda need to mobilize economic power to gain power at the household and community level in order to become empowered and improve the gender relations. Again, the proponents of this theory assume that stratified societies have strata of gender prescribed social roles. These are interpreted as the expected behaviours for men and women in order to fit in society. Both men and women are required to adhere to certain social norms, values and principles advocated by society as a central ideology. The obedience to this expectation on women by society determines their perceptions and in many occasions, confines from participating in activities viewed as men only. These perceptions include the view that women are not breadwinners but homemakers. Men are considered as heads of households and have the power to dictate access and utilisation of family resources including borrowed credit. Women and men, as stated above, are expected to adhere to prescribed gender roles, which they conform to in access, manage and utilisation of any resources within the household, and those in Mbarara and Bushenyi-Ishaka are not exception. For example a good bunch of banana in a woman's plantation belongs to the man while a bull produced by a woman's cow in Mbarara belongs to a man or an elder son (UPPA, 2000). Women therefore occupy lower strata of the society and have little control of productive and non-productive resources which push them into poverty and lack of decision making at household and community level.

Furthermore, the theory identifies women's control of factors of production and economic empowerment as a major contributor to the attainment of power and self-confidence. In regard to that, Blumberg contends that where women have control over their resources like micro-credit, they use them to support family and increase the human capital as opposed to men (Kamau, 2014). The contention given is that women are capable of managing these resources, in ways which help them gain power in households and community. This enhances their decision-making power, and change in gender relations at the household land community level. Further still, Blumberg advocates for socio-cultural inhibitions that dictate women as 
subordinate to men, thus preserving male dominance in the society should be addressed so as to ensure increased household income and gender equality. As such, women's ability to grab economic power lies in their ability to access and manage resources, particularly micro-credit at both the family and community level.

\section{Study population}

\section{METHODOLOGY}

The study population was limited to women borrowers, managers of SACCOs, loans officers and municipal commercial officers. The target population for this study comprised all women who had accessed loans from the SACCO's in the study area between 2014 and 2019. The total population was therefore 209 women comprising of married, single, divorced/separated and the widowed.

This study sought to describe whether access to and utilization of micro-credit programs is a foundation for tackling poverty leading to women economic empowerment. Women in Mbarara and Bushenyi-Ishaka Municipalities of south west Uganda provided contextual setting of the study. Therefore, this study conceptualizes a household as an entity composed by a nonnuclear family. This is composed by a woman, man children and other members of the family. Also targeted were: legally registered mainstream SACCOs which were operating in the area for a long period of time, some from as early as 2000 providing financial services to women. The Mbarara municipality commercial officer provided a list of SACCOs operating within the municipality who had extended credit programs to women. At the time of this study, Bushenyi - Ishaka municipality did not have a commercial officer; therefore the Bushenyi District commercial officer helped me to establish the number of SACCOs operating with the municipality. By the time of this study, Mbarara municipality had 17 registered SACCOs and 17 managers while Bushenyi- Ishaka municipality had 18 registered SACCOs and 18 managers according to the information obtained from the two commercial officers. SACCO managers, loans officers and commercial officers were also targeted in the study. These were key informants with information on women beneficiaries who had accessed microfinance services in the area. They were important since they were involved in the mobilisation of women to access micro-credit programs.

\section{Sampling Strategy}

The study adopted a multi stage sampling strategy which entailed sampling out in stages by use of small and smaller sampling units at each stage proportionately. This involved doing a sample of SACCOs in each municipality, then sampling individual women beneficiaries in the selected SACCOs. It also involved sampling SACCO officers and municipality commercial officers as key informants. The details are demonstrated in 1 figure below: 


\section{Figure 1: Multi stage sampling strategy}

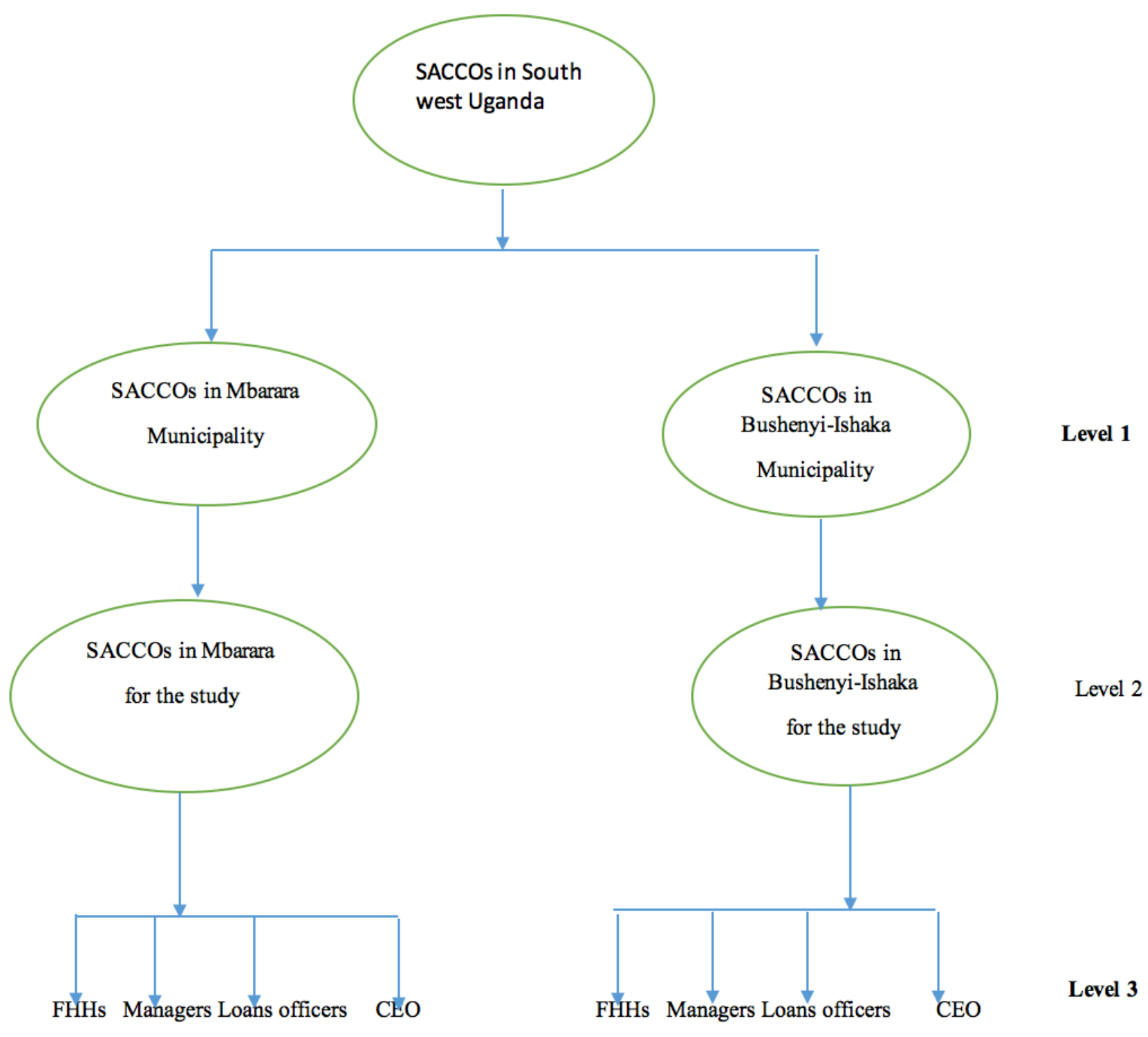

Source: Field data, 2018

Quantitative data statistical Package for Social Sciences (SPSS) software version 20 was used to analyse quantitative data while Qualitative data was analysed using thematic analysis

\section{LIMITATIONS OF THE STUDY}

Although there were many factors that influenced access to micro-credit programs, this study was limited to gender relations factor only. However, gender dynamics are mainly determined by socio-cultural factors. They have the potential to empower or dis-empower women at both household and community level. Therefore, the findings of this study could therefore be generalized to many other areas in Uganda. Important to note however that is beyond sociocultural factors, Mbarara and Bushenyi-Ishaka towns exhibit different forces that influence women's access to micro-credit programs. This means that although the findings, conclusions and recommendations of this study could be generalised to other similar circumstances in other areas in Uganda and across the globe, such generalisation should be done with care. 


\section{Introduction}

\section{PRESENTATION OF RESEARCH FINDINGS, INTERPRETATION AND DISCUSSION}

This section presents analysis of the study data, interpretations and discussions according to the purpose of the study and grounds on gender relations in access to micro-credit services by women in Mbarara and Bushenyi- Ishaka towns in western Uganda. The presentation is guided by theme: factors that influence access to micro-credit programs among women. In addition, the demographic characteristics of women who had accessed micro-credit programs for the period 2014-2019 influenced aspects of access to micro-credit programs by women at the household level.

\section{Respondents' demographic Characteristics influencing access to micro-credit programs}

The demographic characteristics for the women respondents who had accessed micro-credit programs that is analysed include age, marital status, level of formal education and number of children who are dependants, as shown in Table 3.2.

Table 3.2: Demographic characteristics of women borrowers

\begin{tabular}{|c|c|c|c|}
\hline & Particulars & Frequency & Percentage \\
\hline \multirow[t]{7}{*}{ Age (in years) } & Below 20 & 4 & 2.2 \\
\hline & $20-25$ & 16 & 8.8 \\
\hline & $26-30$ & 25 & 13.7 \\
\hline & $31-35$ & 68 & 37.4 \\
\hline & $36-40$ & 55 & 30.2 \\
\hline & Above 41 & 14 & 7.7 \\
\hline & & 182 & 100 \\
\hline \multirow[t]{6}{*}{ Marital status } & Single & 10 & 5.5 \\
\hline & Married & 96 & 52.7 \\
\hline & Widowed & 24 & 13.4 \\
\hline & Divorced & 20 & 10.9 \\
\hline & Separated & 32 & 17.5 \\
\hline & & 182 & 100 \\
\hline \multirow{6}{*}{$\begin{array}{l}\text { Level of formal } \\
\text { Education }\end{array}$} & No formal education & 38 & 20.9 \\
\hline & Primary & 75 & 41.2 \\
\hline & 0 level & 50 & 27.5 \\
\hline & A level & 10 & 5.4 \\
\hline & Tertiary education & 9 & 5.0 \\
\hline & & 182 & 100 \\
\hline \multirow{6}{*}{$\begin{array}{l}\text { Number of children } \\
\text { Depending on women }\end{array}$} & None & 15 & 8.2 \\
\hline & $1-2$ & 39 & 21.4 \\
\hline & $3-4$ & 51 & 28.0 \\
\hline & $5-7$ & 49 & 27.0 \\
\hline & More than 7 children & 28 & 15.4 \\
\hline & & 182 & 100 \\
\hline
\end{tabular}

The age of selected women borrowers is an important variable in access to micro-credit programs. The study revealed that of the 182 women respondents who had accessed microcredit 2.2\% were below 20 years while $8.8 \%$ were between the ages of $20-25$. Those aged between 26 and 30 were 13.7, while 7.7\% were between the ages of 31-35. The findings show that a high section of women borrowers who had accessed micro-credit programs were within the $36-40$ age bracket (37.4\%), followed by those above 41 years at $30.2 \%$. The borrowers below 20 years of age were the minority at $2.2 \%$. This specifies that young women formed the lowest numbers of women accessing micro-creditprograms at the time of the study. Thus young women are not accessing micro-credit as expected. During an interview with the loans officer, He explained that young women lack the necessary entrepreneurial skills and experiences to effectively manage business loans. The study is in agreement with Sweetman 
(2001) who also found out that young females discriminated against by lending institutions due to their age. Discussions with women respondents revealed that lending institutions were reluctant to give loans to those who were below the age of 18 years.

Loans officers also informed the study that they preferred to offer loans to older women, above 30 years, as indicated by figures in Table 3.2, because they are assumed to have the relevant experience in business enterprises, are mature and have a high possibility of repaying loans. One MFI officer confirmed to the study that this category of women, "are dependable since they are settled in their homes, as compared to young women who are 'likely' to get employment or get married and move away with their husbands and settle elsewhere with their new families". This means that age Influences against young women, biases them to career mobility, a factor that limits their access to micro-credit programs. Nevertheless, loans' officers also exposed that the upper age limit of females accessing loans is 60 (though not included in table 3.2). According to them, women above this age are unable to run businesses successfully. On the other hand respondents revealed that women below the age of 20 years were discouraged from accessing loans due to lack of legal documents. This finding also concurs with the views of Sweetman (2001) in a study on 'Gender, Development and Money in Cameroon', who observed that women were discriminated against by the micro-lending institutions on grounds of age, which in turn affected their access to loans. A Similar study by Kamau, (2014) on Kenya's microcredit institutions also found out that young borrowers were mobile and easily changed places of work resulting into loan default. Therefore young women as well as the elderly women are at risk wallowing into poverty compared to middle aged women who access microcredit programs for economic empowerment.

Marital Status of the borrowers revealed that the majority of those who accessed micro-credit programs were married women at $52.7 \%$. Table 3.2 shows that $5.5 \%$ women borrowers were single, $13.4 \%$ were widowed and $10.9 \%$ were divorced while $17.5 \%$ separated. From the results shown in Table 3.2, married women formed the majority of those accessing microcredit programs as compared to divorced and separated, widowed and single women. One loan's officer confirmed this in his statement that: According to our records, single women are few, and form the major loan defaulters as compared to other categories of women. A study by Kamau, (2014) in Kenya found out that the loan default rate of single, widowed and divorced was higher than the married women. Study findings by Nawai, Shariff, (2012) in Malaysia also revealed that single women were viewed as possible defaulters because they were thought to be more likely to relocate upon marriage, unlike the married ones. Nonetheless, $13.4 \%$ widowed women also revealed that they were free to access loans without consulting male relatives to access resources, as traditionally expected. They had power to decide on when to access micro-credit programs without consultation, unlike their married women counterparts. However, in support of marital status as a factor that influenced access to micro-credit programs. One women respondent informed the study that she had to get permission from her husband before applying for a loan from SACCOs as heads of households. This finding is consistent with Wood (2011), who states that gender relations are initiated by men in society from a position of power and maintained in households by them as they enjoy the benefits of that power over women.

The Level of formal education of women borrowers is yet another demographic characteristic that was found to influence access to micro- credit programs. The table above shows that female borrowers who had no formal education were $20,9 \%$, those who had attained primary education were $41.2 \%, 27.5 \%$ had ' 0 ' level secondary education and $5.4 \%$ had ' $A$ ' level secondary education and $5.0 \%$ had tertiary education by the time of this study. Formal education played a key role in access to micro-credit programs by women, since it gave them 
confidence to approach SACCOs. Discussions with women beneficiaries revealed that $27.5 \%$ of those with secondary education and above had used their formal education to make personal decisions regarding access to micro-credit programs without consulting their husbands. They confirmed that this was made possible because they were able to access the necessary information about micro-credit programs. In regard to this, two women respondents reiterated that they were able to access information which helped them access resources from more than one SACCO. Other women respondents confirmed that formal education enabled them to access information from media and social networks for innovative business ideas, which helped in setting up income generating projects that increased their household incomes. Confirming the same, another female respondent had this to say: 'Since I have a diploma in Business administration, I was able to carry out a feasibility study to assess setting up a computer software business with the resources from SACCOs'. "I made a cash forecast which gave me an idea on how much I needed to borrow from SACCOs. In contrast, the study established that women with no formal education and those with primary education had limited or no access to business start-up information. As such, they were not able to access any information to start their businesses and thus concentrated on traditional enterprises based on their gender roles. The study finding concurs with Mohamed (2012) findings. Mohamed noted that women's enterprises are influenced by the concept of gender making them lack basic information on diverse business ideas. The findings show that 'feminised' businesses do not depend on level of education of information to start up. Hence they are unlikely to mobilise enough incomes to economically empower women, and change gender relations in households. A study by Luyirika (2010) also found out that women who had attained formal secondary education were able to fill loan application forms without any hurdles compared to those with primary education.

The number of children dependant on female borrowers was also put into consideration. The study considered the number of children in terms of dependency ratio, which is defined as the number of children who are pendants within a household outside the working age (Kamau, 2014). As shown in Table 3.2, women with no children formed 8.2\%, while those with 1-2 children made up 21.4\%, and those with 3-4 children formed $28 \%$ of the total respondents. Those with 5-7 children were $27 \%$ of the total respondents and those with more than seven children formed $15.4 \%$. High number of dependants means that women have to supplement household incomes, hence family size is a major influencing factor in women's access to microcredit. Size of the family affects loan usage and repayment. For example during a FGD it was confirmed that large number of children means an increase in family needs, consequently making them join SACCOs to meet them which later affects credit utilization and household incomes. This finding is in agreement with the feminist conflict theory by Blumberg (1984), which proposes that women access credit to support children at household level. The study findings are consistent with the studies of various scholars such as Yunus (2007), Claessens and Krantz (2001), who observed that the number of children in a family is a major drive for women to access and utilize micro-credit services, to enable them maintain their families. This improves gender dynamics between women and their husbands or male relatives due to income contribution by women in the household to support the family. However, it leads to poor loan repayment that tantamount to women disempowerment and low investment.

On the other hand, female borrowers were required to mortgage assets to SACCOs as loan securities. Yet, some of the women cross-examined moaned that they found it difficult to access loans because they did not own assets in their own right. Most household assets including those bought by women belonged to men as they were registered in the names of their husbands. It's within the African cultural context that women are not expected to own any asset within the household or community. Similarly, married women in Uganda have to seek 
consent from their husbands in order to mortgage property in their own possession to SACCOs. Sometimes women are denied permission to do so as lamented by one of the respondents during an interview. Respondents reported that it was a requirement by SACCOs that husbands and local council one (LC1) authorities endorse by signing the loan application forms and loan agreements as guarantee for repayment which also influences women's access to micro-credit programs and poverty status. They further reported that widowed women are required to sign affidavits with Lawyers to show that collateral belongs to them. The study findings were in agreement with previous scholars like Yogendrarajah (2013) in Sirilanka and Kamau (2014), in Kenya, both scholars researched on the challenges faced by women in accessing credit from MFIs and among other factors found out that women have to seek for signatures as a formal permission from their husbands so as to mortgage assets for loan access which can be denied at times. This shows the extent to which men exercise their power to deny women from accessing assets as collateral, thereby limiting their potential to engage in meaningful ventures. This finding is in agreement with Sweetman (2001), Wood (2011) who argued that marriage commands gender dynamics in households, which in turn specifies property and ownership rights. The implication is that in the absence of a husband women's access to family assets is doubtful. Further still, gender dynamics in households influence access to economic resources by females in all categories. This was confirmed during an interview with loans who also consented that assessment was done so as to ensure that property mortgaged belonged to them, but not other family members. This is in agreement with the literature reviewed and Blumberg feminist conflict theory which advocates for society's stratification in the African culture, spells out the power of ownership of property and gender relations in families. This finding is also confirmed by Gachara (2012, Wamue and Njoroge (2011) who concluded that marriage also influences out property ownership in a family. Therefore, if micro-credit programs are set out to assist the poor who lack collateral to access micro-credit credit, and again demand prove of their wealth, which provision of collateral entails then tackling poverty through micro-credit programs remain a myths. Generally, micro-credit programs were established to help the poor who do not have collateral, have low incomes among others. It is then a contradiction to set out to help women and set up strict procedures limit them from accessing the intended programs. This situation defeats the central hypothesis of poverty reduction and empowerment through micro-credit programs in Uganda and elsewhere in developing countries.

\section{CONCLUSION}

The purpose of this study was to determine the factors that influence access to Micro-credit programs by women in Mbarara and Bushenyi-Ishaka towns. The findings disclose that corporate factors comprise of age, marital status, formal education level and collaterals. Findings also reveal that old women are not able to access micro-credit because of their advanced age. Likewise, those aged below 18 years cannot access micro-credit because they are regarded as minors in business transaction, lack experience and entrepreneur skills. Married women are preferred by SACCOs because they are unlikely to move away from their households upon accessing loans as compared to young single women. Single women are discriminated against because SACCOs see them as potential defaulters likely to relocate upon marrying and default on loan repayments.

In addition, women with formal education had accessed information from various sources. They were able to carry out market assessment, which formed the basis of their innovative businesses ventures, as compared to those with no formal education who were unable to access such information. The number of children a woman has influences her access to microcredit programs. This is because such a woman accesses credit to meet basic family needs. Again, lack of collateral influences access to micro-credit, since men as heads of households 
own and control all assets required as security by SACCOs. Thus gender relations in households demand that married women consult their husbands to allow them mortgage household assets for collateral; failure to do so raises conflict at family level. Considering that SACCOs are founded to help the poor who do not have collateral, it is then illogical to set out to support them and set up constraining terms and conditions, which provision of assets as collateral for loan security entails. The requirement that husbands and local council authorities to sign the loan application forms as guarantee for repayment also influences women's access to micro-credit. Widowed women are required to sign affidavits with Lawyers to show that collateral belongs to them. This denounces their status and influences access to micro-credit programs. This requirement dictates against access to microcredit by FHHs in Mbarara and Bushenyi-Ishaka towns. This implies that patriarchy is embedded in micro lending institution procedures. This is absolute gender acumen, which is likely to bring conflict in households when signatures are denied, thus affecting gender affairs and households incomes, as the same is not expected of the other gender. These findings are in line with Blumberg theory that gender stratification dictates ownership of productive assets used for collateral in access to micro-credit programs. These findings confirm the first premise of the study certain that prime factors influence access to micro-credit programs by women.

\section{RECOMMENDATIONS}

Based on the study's findings, the following are the recommendations for enhanced access to micro-credit programs by women. Thus SACCOs need to review some of the practices which were introduced two decades back. More wide-ranging strategies are necessary. For example SACCOs should:

[1] Penetrate and reach out even to the needy people in urban and rural areas and appreciate the socio-economic conditions of women, knowledge, attitudes, religious and political affiliations, perceptions and cultural beliefs of the people they serve. A critical consideration of these issues will enable SACCOs in the $21^{\text {st }}$ century to tailor their financial services to the needs of Ugandans.

[11] Introduce grace period for loans to allow businesses make enough to repay loans and re-invest the rest. Whereas some businesses in Uganda are able to repay loans without grace periods, others are unable, and suggested a grace period of at least six months to allow businesses to make enough returns to repay the loans.

[111] Introduce different types of collateral like group formation instead of household assets. Most women, boda boda and tax drivers lack collaterals like household assets which in most cases are a requirement for one to access loans. SACCOs should introduce additional collaterals like operational businesses, academic documents that are privately owned by loan seekers. Those without collaterals can guarantee each other under group or cluster formation. This would enable access to SACCO services without seeking permission from husbands for married women and youth seeking permission from their parents to use household assets as collaterals

[1V] Introduce friendly and flexible loan repayment schedules in accordance with ability of business to make loan repayments. In my opinion, the repayment period should be based on business turnovers and business ability to repay, rather than a fixed period for all enterprises. For example someone operating salon and boda boda and taxi business in Uganda can manage weekly or monthly loan repayment, another one operating agrobusiness may not. For example, in Malaysia, borrowers involved in dairy farming are allowed to pay their loans according to the milking cycle. Loan repayments in Malaysia are also paid on the basis of cash flow cycle of the borrowers' business. Loan flexibility is a key player to stimulate borrowers to invest their loans more profitably.

[V] Formulate gender sensitive policies to address collateral requirements so as to aid women access loans. For example, the savings the women have with SACCOs should be 
used as collateral. In addition, group co-guarantee is collateral that women can provide as loan security. They should also develop training products that address the other needs of women such as gender, division of labour and consult women on the appropriate timing of any training, for them to fully participate without disrupting gender roles in their homes. SACCOs financing paradigm should be regarded as an integrated program with other interventions if national economic empowerment is to be achieved and thus Vision 2040 in Uganda.

[V1] Let SACCOs display information in regard to loan application and loan disbursement by the use of posters in SACCO offices and notice boards placed in strategic places where the public can review information as part of accountability to trap the corrupt SACCO officers but also for information to flow easily.

[V11] Introduce appropriate loan sizes in accordance with one's business needs through consultations and realistic interest rates in line with the micro-credit Act in Uganda and introduce new repayment periods based on business capacity to repay the loans. Extending the size of the loan or loan volume works very well in Kenya among the Youth entrepreneurs. The same idea can borrowed to suit the Ugandan situation.

[V111] Reduce the initial loan acquisition costs in order to improve on access and utilization of SACCO services and practices. There is need to reduce the initial loan acquisition costs. The monetary requirement for one to access loans is among the impediments to access SACCO services. The monetary costs swallow up the profits, rendering the businesses weak and lacking in financial sustainability. The high cost of loan acquisition is tantamount to buying a loan which adds an injury to the wound as the old saying goes. This does not only reduce the level of profitability but also results into indebtedness and continuous gender poverty. In other words there is need to reduce the percentage transaction cost of borrowing from SACCOs so as to attract more clients.

[1X] speeding up loan processing and disbursement to encourage Ugandans participation in the SACCO financing programs: One of the challenges of lending through SACCOs is the delays in executing loans. It takes a long time for one or a group to access the loan services from the SACCO. The procedures involved like filling so many documents, appraisal visits, guarantors' photographs, signature requirements and getting recommendations from local council leaders or employers and in this case RDCs since it is a government program has been taking long. Although one would argue that these correct procedures reduce on defaulting rates, one would also counter argue that these steps should not take a lot of time as it discourages the borrowers and contributes to loan diversion. In some cases, the borrowers may lose business engagements as a result of loan delays.

[X] In this contemporary world, strategic learning for a change is one such value for any individual and organization. Majority of the poor who access loans are less qualified to effectively and efficiently use it. Therefore, I strongly recommend that further training in business management, work ethics, professionalism and entrepreneurship is imperative for the sustainability of the credit business. Although SACCOs try to provide elementary training, a lot has to be done in that more capacity building of the borrowers is needed to sustainably manage the micro enterprises and subsequently be able to service the loan without stress. Such training initiatives should not be limited to SACCOs but also through the credit solidarity groups to constitute themselves into information and experience sharing social support network system. 


\section{References}

Agriculture Support Programme (2010). Savings and Credit Cooperative Society (SACCOS) Development process. Available at: http://asp.ramboll.se /Docs/ savings

Blumberg, L. (1984). A General Theory of Gender Stratification. New York: Jossey- Bass.

Blumberg, L. (2005).Women Economic Empowerment as the "Magic Potion" of Development. University of Virginia and California

Chafetz, J. (1990). Gender Equity: An Integrated Theory of Stability and Change. New Burry Park CA: Sage.

Cleaver, F., \& Hamada, K. (2010). 'Good' water governace and gender equity: A troubled relationship. Gender and Development, 18(1), 27-41.

Ebimobowei, Sophia, \& Wisdom, (2012), An Analysis of microcredit and poverty reductionin Bayelsa state of Nigeria. Arabian journal of business and management review, 1(7), 38-57

Gachara, M. (2012).Metaphors of Gĩkũyũ Marriage Negotiations: A Cognitive Linguistics Perspective.PHD Thesis, Kenyatta University.

Grabka, M. M., Marcus, J., \& Sierminska, E. (2013). Wealth distribution within couples. Review of Economics of the Household, 11(4). doi:10.1007/s11150-013-9229-2.

Helms, B. (2006).Access for All: Building Inclusive Financial Systems. Washington, D.C: The World Bank.

Kamau P. W (2014). Gender Relations in Access, Control and Utilisation of Microcredit Resources: A Case of Women in Kiharu Constituency Kenya. Kenyatta University

Seyed, Majid, Nurulizwa, Mohd \&Hamid (2013).The role of microcredit on the wellbeing of poor people. Case studies from Malayasia and Yemen. Accessed 23 ${ }^{\text {rd }}$ December, 2017 on URL: http://dx.doi.org/10.5539/ass.v10n1p230

World Bank. (2007). Global monitoring report: Confronting the challenges of gender equality and fragile states. Washington, DC: The World Bank.

Kariuki, J. G. (2013). Feminisation of Poverty in Kenya.The Case of Abagusii and Agikuyu Women in Kenya. International Journal of Arts and Entrepreneurship, 1 (5): 372-383.

Luyirika, N.M. (2010). The role of microcredit in the socio-economic development of women in a community. A case study in Mpigi T.C University of S. Africa

Nawai, N., \& Shariff, M. N. M. (2012). Factors affecting repayment performance in microcredit programs in Malaysia. Procedia - Social and Behavioral Sciences, 62(24), 806.

Niehof, A., \& Van Tilburg, A. (2010). The livelihood strategies of women fish traders in adapting to cultural and institutional constraints in Ibaka, Nigeria. Maritime Anthropological Studies, 9(2), 65-93.

Nwigwe, C. A., Omonona, B. T., \& Okoruwa V. O. (2012). Microcredit and Poverty Reduction in Nigeria: A Critical Assessment. Australian Journal of Business and Management Research Vol.2 No.04

Schincks, P. (2010). Micro Finance for Sustainability in Ghana. New York: United Nations Development

Programme. Schwandt, T. A. (2001).Dictionary of Qualitative Inquiry, 2nd Edition. Thousand Oaks. CA: Sage.

Sweetman, C. (2001). Gender, Development and Money. London: Oxfam Publication.

Wamue, G. and Njoroge, N. (2011). Gender Paradigm Shift within the Family Structure in Kiambu, Kenya. African Journal of Social Sciences, 1 (3): 10-20.

Wood, J. (2011). Gendered Lives Communication, Gender and Culture. Boston: Wadsworth.

UPPAP. (2000). Ministry of Finance, Planning and Economic Development, Kampala

Yogendrarajah, R. (2013). Challenges faced by women in accessing credit from Microcredit Institutions in Srilanka. The international journal of Economics and business management. East Publications

Yunus, M. (2007).Creating a World without Poverty: Social Business and the Future of Capitalism. New York: Public Affairs Publishers.

Yunus, M. (2012). A Conceptual Framework: Role \& Impact Relationship between Micro Finance and Poor's Access. Journal of Contemporary Research in Business.3 (10): 717 -732. 